\title{
Die konstellasie taalbegrip-logika in die Middeleeuse filosofie (2): Duns Skotus tot De Rivo
}

\author{
Author: \\ Johann Beukes ${ }^{1}$ \\ Affiliation: \\ ${ }^{1}$ Department of Philosophy, \\ University of Johannesburg, \\ South Africa

\section{Correspondence to:} \\ Johann Beukes \\ Email: \\ jbeukes@vodamail.co.za \\ Postal address: \\ PO Box 784849, Sandton \\ 2146, South Africa \\ Dates: \\ Received: 10 June 2011 \\ Accepted: 22 Dec. 2012 \\ Published: 02 May 2012 \\ How to cite this article: \\ Beukes, J., 2012, 'Die \\ konstellasie taalbegrip-logika \\ in die Middeleeuse filosofie \\ (2): Duns Skotus tot De Rivo', \\ HTS Teologiese Studies/ \\ Theological Studies 68(1), \\ \#Art. 1112, 12 pages. http:// \\ dx.doi.org/10.4102/hts \\ v68i1.1112
}

(C) 2012. The Authors.

Licensee: AOSIS

OpenJournals. This work

is licensed under the

Creative Commons

Attribution License.
The constellation language-logic in medieval philosophy (2): Duns Scotus to De Rivo. This second in a series of two articles continues the attempt to provide an in-depth overview of some of the most prominent - and some of the most underpublished - medieval thinkers' stances on the constellation of language and logic, thus as a combined and condensed problem in western philosophy between the 5th and 15th centuries. The two articles form part of a rehabilitating series of modern-critical articles on understated and marginalised themes, texts and figures in medieval philosophy. The positions of the well-known philosophers that are covered in the two articles, St Augustine, Peter Abelard, St Thomas Aquinas, John Duns Scotus and William of Ockham, are juxtaposed with some less familiar philosophical positions, amongst others those of Boethius, Peter of Spain, John Wyclif and Peter de Rivo.

\section{Johannes Duns Skotus: Univocatio, modietratiosignificandi}

Hierdie laaste in 'n reeks van twee artikels ${ }^{1}$ kontinueer die poging om 'n intensiewe oorsig van die mees prominente - en daarteenoor sommige van die mees ondergepubliseerde - Middeleeuse denkers se posisies ten aansien van die konstellasie taalbegrip-logika, as dus 'n samehangende probleem in die Westerse filosofie tussen die 5 de en 15de eeue, te verskaf. Die perspektiewe van bekende Middeleeuse filosowe soos Augustinus, Petrus Abelardus, Thomas Aquinas, Johannes Duns Skotus en Willem van Ockham, word in hierdie twee artikels jukstaponeer ${ }^{2}$ met die minder bekende en tradisioneel ondergepubliseerde perspektiewe van onder meer Boethius, Petrus Hispanus, Johannes Wyclif en Petrus de Rivo.

Die vorige artikel het 'n oorsig vanaf Augustinus na Aquinas, via Boethius, Abelardus en Petrus Hispanus, verskaf. In hierdie artikel word die latere skolastiek by monde van Johannes Duns Skotus en Willem van Ockham, maar ook die minder bekende Johannes Wyclif en Petrus de Rivo, ten aansien van die konstellasie taalbegrip-logika, aan die woord gebring. In die vorige artikel is Aquinas se teorie van analogiese ekwivokaliteit slottenderwys bespreek. Met hierdie analogiese posisionering van die verhouding tussen taalbegrip en logika het Aquinas die tafel gedek vir die latere skolastiek van die $14 \mathrm{de}$ en $15 \mathrm{de}$ eeue om op die konstellasie vanuit die logica vetus na die logica novus, voort te borduur. Johannes Duns Skotus en Hendrik van Gent was die eerste skolastici uit die laat 13de en vroeg 14de eeue om grondig hierop te reageer.

Die Franciskaan Duns Skotus ${ }^{3}$ (1266-1308 ), gebore te Duns naby Berwick-Tweed in Skotland en oorlede op die jong ouderdom van 42 te Keulen, staan in die Middeleeuse filosofie met goeie rede bekend as Doctor Subtilis, 'die subtiele doktor': sy werk in Franciskaanse kloosters en die teologiese fakulteite te Cambridge, Oxford, Parys en Keulen getuig van 'n ideehistoriese aandag aan die fynste detail, intensiewe nuanses in die hantering van die intellektuele voorgeskiedenis en 'n voorkeur aan subtiele onderklemtoon in skolastiese polemieke. Skotus se subtiliteit manifesteer juis kenmerkend in sy hantering van die konstellasie taalbegrip-logika

1.Vir die eerste artikel, kyk 'Die konstellasie taalbegrip-logika in die Middeleeuse filosofie (1): Augustinus tot Aquinas' (2011b). Alle metodologiese verantwoordinge in voetnotas en in die hoofteks van genoemde artikel word in hierdie tweede artikel sonder herhaling vooronderstel.

2.Resepsie geskied sover moontlik vanuit die primêre tekste aan die hand van die seleksies en tekstuele geleiers van Bosley en Tweedale (2004), Copleston (1972), Kenny (2005), Luscombe (2004) en Marenbon (2007), hoewel betroubare Engelse en Duitse vertalings vanuit die Latyn gebruik is, waar nodig, vir semantiese kontroledoeleindes. Die eeue-oue gebruik om na Middeleeuse denkers, veral monnike, te verwys met onderklemtoon op die voornaam en met klem op die geboorteplek, dus byvoorbeeld na Johannes Duns Skotus binne die konteks van ' $\mathrm{n}$ resumering of bespreking bloot as 'Skotus' te verwys of na Willem van Ockham bloot as 'Ockham', is taalkundig korrek in Latyn maar eintlik nie korrek in tale soos Afrikaans waar ' $n$ genetief naamval ontbreek nie. Ter wille van terminologiese instandhouding en ensiklopediese gelykblywendheid, word die gebruik in die Afrikaanse taal gehandhaaf.

3.Skotus, soos Augustinus, Abelardus, Anselmus, Aquinas en sy laat-skolastiese opvolger Willem van Ockham, is in die filosofiegeskiedenis en eietyds steeds uiters goed gekommentarieerd, veral vanuit die versamelwerke Opera Omnia (1950/1968) en Scotus Opera Philosophica (1997) asook in die kompilasiewerke van die Internasionale Franciskaanse Vereniging by http://www.franciscan-archive. org/. Die belangrikste en mees uitstaande monografie-kommentare en teksanalises op Duns Skotus oor die afgelope jare sluit in org/. Die belangrikste en mees uitstaande monografie-kommentare en teksanalises op Duns Skotus oor die afgelope jare sluit in Bos (1998), Broadie (1995), Cross (1999), Ingham (2004), Sylwanowicz (1996), Vos (2006), Vos (Jaczn), Veldhuis, Looman-Graaskamp, besonder die resente bloemlesing van Bosley en Tweedale (2004:284-300, 329-334, 404-418) en daarby die uitstaande seleksies en kommentare in Copleston (1972:219-226), Kenny (2005:140-143), Luscombe (2004:124-132) en Marenbon (2007:7221-7251). Soos kommentare in Copleston (1972:219-226), Kenny (2005:140-143), Luscombe (2004:124-132) en Marenbon (2007:7221-7251). Soos
met die geval in die eerste artikel, verskaf hierdie vyf kommentare die belangrikste tekstuele en tematiese geleiers asook seleksieskopus vir die onderhawige navorsing oor Skotus se hantering van die saak. 
deur 'n verfynde polemisering van Aquinas se analogiesekwivokale posisie, deur nie Aquinas self nie, maar Gent se middelweg-eksponering van Aquinas te problematiseer. Gent gebruik Aquinas se analogiese teorie om die tese van die onherleibaarheid van die Goddelike en skepselmatige tot enige een enkele konsep te verdedig. Skotus se perspektief is daarteenoor dat daar ' $n$ enkele konsep van syn is wat univokaal ondervang moet word.

Om Skotus se univokale teorie en polemiek met Gent-Aquinas te verstaan, is dit nodig om eers te vertoef by 'n basiese en wesenlike onderskeid in sy hantering van die konstellasie taalbegrip-logika, naamlik tussen modale en formele werklikhede. Wanneer ons tussen twee sake onderskei, gestel $a$ en $b$, het ons normaalweg wat Middeleeuse denkers gangbaar ' $n$ 'reële onderskeid' genoem het, in gedagte: $a$ en $b$ is twee numeries verskillende dinge; my studietafel en die koffiebeker wat daarop staan, of die koffiebeker en soortgelyke koffiebekers in die kabinet. Maar ons maak ook soms konseptuele onderskeide, wat gangbaar in die Middeleeue 'redelike onderskeide' genoem is, wat 'n onderskeid is wat gebaseer is op hoe ' $\mathrm{n}$ saak verstaan word: ons onderskei tussen die oggendster en die aandster, hoewel dit dieselfde saak of objek is, naamlik die planeet Venus (vgl. Marenbon 2007:7188). Die onderskeid word gemaak op grond van 'n redelike ingrepe op $a$, nie- $b$, maar wat wel $a 1$ en $a 2$ tot gevolg het. Skotus voeg egter by hierdie twee soort onderskeide, reël en redelik, ook twee ander onderskeide, wat wel ' $n$ basis in die werklikheid het, maar nietemin nie reële onderskeide is nie. Veronderstel $a$ en $b$ is werklik identies (wat vir Skotus beteken dat dit logies onmoontlik is dat $a$ en $b$ geskei behoort te word), maar $a$ en $b$ het subtiel-verskillende definisies of moet met uiteenlopende, bykomende begrippe gespesifiseer word: dan is $a$ en $b$ vir Skotus 'formeel onderskeibaar', of formalitates. Skotus (1950:16.260) regverdig hierdie formele soorte onderskeid, naas dus reële en redelike onderskeide, deur te argumenteer dat indien dit inderdaad nodig is om die identiese $a$ en $b$ met bykomende of uiteenlopende begrippe te spesifiseer, daar logieserwys iets in die natuur of 'vorm' (in die Aristoteliese sin van die woord) van $a$ en $b$ is wat $a$ en $b$ noodsaaklik onderskeibaar maak. Hoewel Skotus se formalitates ' $n$ gevestigde Middeleeuse oortuiging, minstens sedert die dialektiek van Abelardus, rondom 'subtiele onderskeide' bloot eksplisiet maak, vestig die waarde van die onderskeid daarin dat dit as ' $n$ derde, genuanseerde soort onderskeid naas reële en redelike onderskeide in die taalbegrip-logika van die laat 13 de eeuse skolastiek gevestig word.

Skotus maak uiters idiosinkraties egter ook 'n vierde onderskeid, naamlik modale onderskeide. Wanneer 'n mens op 'n kleur en uiteindelik op 'n skakering van die betrokke kleur vir die verf van byvoorbeeld 'n biblioteek se binnemure moet besluit, kan daar gekyk word na verskillende voorbeelde van 'n spesifieke kleur, byvoorbeeld beige. Al die voorbeelde is beige, maar varieer op grond van onder meer tekstuur, helderheid, enamelskyn, tot die kleur van bykans dowwe ligbruin. Al die kleurvoorbeelde is beige, maar is 'verskillend beige'. Waar Abelardus sou stel dat byvoorbeeld die enamelskyn van die een voorbeeld ' $n$ geheel ander eienskap as die beige van die betrokke voorbeeld is, sou Skotus kies om van verskillende modi of modaliteite van die eienskap 'beige' te praat, wat ' $n$ intrinsiek, binne-ontleende oorweging is. Die modale onderskeid tussen 'n eienskap of attribuut van 'n saak en die intrinsieke modi daarvan is, soos met formele onderskeide, gebaseer in die werklikheid, maar moet pertinent intrinsiek gespesifiseer word.

Skotus verwerp juis op grond van die nosie van modale onderskeid en via sy polemiek met Gent die Aquiniese teorie van analogiese ekwivokaliteit, sowel inhoudelik as in terme van die toepassing daarvan op religieuse taal. Daarmee vestig Skotus 'n unieke posisie in die skolastiek, naamlik dat die onderskeid tussen God en God se skepsels nie ekwivokaalanalogies is nie, maar op grond van die nosie van modale onderskeid, univokaal is. Skotus neem vanaf Avicenna die perspektief oor dat die subjek van metafisika syn qua syn is en dat ons 'n nosie van syn begryp wat geheel onbetrokke staan teenoor die goddelikheid aldan nie daarvan. Maar Skotus gebruik hierdie opvatting anders as sy Arabiese voorganger, wat teologie deel wou maak van 'n 'universele wetenskap' wat die gemene karakter aan alle wesens, ook God, wou ondersoek: vir Skotus gaan dit oor 'n integrerende metafisiese benadering ten opsigte van een tak (wat ons vandag 'natuurlike teologie' sou noem) van die groter teologiese ensiklopedie, waarin God en God se skepsels in terme van 'n enkele nosie met modale onderskeide, verstaan sou kon word.

Skotus (1950:16.260) argumenteer dat indien dit hoegenaamd moontlik is om wel oor God te praat, daar woorde sou moes wees wat dieselfde betekenis sou moes dra wanneer hulle van toepassing gemaak word op beide God en God se skepsels. Die teologiese diskoers in toto kan nie analogies wees nie: sommige aspekte van die diskoers moet univokaal ${ }^{4}$ wees. Skotus fokus in hierdie argument by voorkeur op wat hy benoem as 'transendentale' konsepte, waarmee hy baie spesifiek - anders as in die moderne, veral by Kant bedoel dat sodanige woorde die grense tussen Aristoteles se tien kategorieë of praedicamenta $a^{5}$ transendeer en op almal

4.Teenoor die Aquiniese posisie van volstrekte analogie in die teologiese diskoers Aquinas argumenteer dat wanneer ons woorde gebruik om oor God en mense te praat, ons dieselfde woorde (byvoorbeeld liefde, of vryheid) gebruik, maar hierdie 'dieselfde woorde' word nie dieselfde gebruik nie; eerder analogies dieselfde, hetsy per attribuut of per proporsie. Wanneer ons beide God en Sokrates 'wys', noem, per attribuut of per proporsie. Wanneer ons beide God en Sokrates "wys' noem, gebruik ons dieselfde woord, sonder om dit as metafoor te wil gebruik. Ons gebruik dit spontaan analogies (Aquinas 1964:1a13): 'Hierdie gebruik van woorde vestig iewers tussen suiwer ekwivokaliteit en eenvoudige univokaliteit, omdat die woord nooit in dieselfde sin gebruik word nie, soos wat dit met univokaliteit die geval sou wees, maar ook nie heeltemal verskillend nie, soos wat die geval met ekwivokalitei sou wees.' 'Univokaliteit' dui op ' $n$ term wat in dieselfde sin op meer as een tipe saak van toepassing gemaak kan word, sonder verlies aan inhoud. 'Ekwivokaliteit' daarteenoor, dui op ' $n$ term wat nie in dieselfde sin op meer as een tipe saak van toepassing gemaak kan word sonder verlies of wysiging aan inhoud nie.

5.Aristoteles se tien kategorieë of praedicamenta behels enige iets wat die subjek of predikaat van 'n stelling kan wees. In Categoriae (1995:3-25) argumenteer Aristoteles dat die voorwaardes vir die praedicamenta, die antepraedicamenta, 'n vierledige struktuur behels, wat self ontstaan vanuit twee basiese spraakvorme, of spraak-assyn, naamlik eenvoudig (bv. 'die vrou') of kompleks (bv. 'die vrou loop'), terwyl slegs laasgenoemde komplekse spraakvorme waar of vals kan wees. Vanuit alle dinge wat laasgenoemde komplekse spraakvorme waar of vals kan wees. Vanuit alle dinge wat bestaan, is (1) sommige dinge predikate van ' $n$ subjek, maar nie teenwoordig in ' $n$ subjek nie; (2) sommige dinge in ' $n$ subjek, maar nie predikate van ' $n$ subjek nie; (3) sommige dinge in sowel ' $n$ subjek as ' $n$ predikaat van die subjek; en (4) sommig dinge nie in ' $n$ subjek of in enige predikate van die subjek nie. Die tien praedicament val voorwaardelik op die antepraedicamenta terug: (a) Ousia/Substantia [of tode of ti esti-substansie, 'dit' of 'wat dit is'], wat nie gepredikeer kan word ten aansien van enige objek nie en wat nie in 'in' enige objek is nie (bv. 'vrou', 'Mary' 'Mary is 
van toepassing gemaak sou kon word. Skotus (1950:16.266) argumenteer dat sodanige 'transendentale' konsepte almal univokaal is: hulle dra 'n eenduidige betekenis, of hulle nou op verskillende soorte skepsels of op God self van toepassing gemaak word. Die mees wesenlike transendentale konsep is daarom ens, 'om-te-wees', of syn: God en skepsel, en die verhouding substansie-eienskap, reflekteer almal dieselfde ens in presies dieselfde sin van die woord. Ander transendentale konsepte, soos Skotus dit hanteer, sluit begrippe soos 'die goeie' en 'vrye wil' in.

Gent se kompromissoekende posisie was dat die onbedinkbare (inderdaad 'n Dasein-agtige premisse van die 20ste eeuse Heidegger) konsep van syn twee onderskeibare konsepte maskeer, die eerste sou van toepassing wees op die oneindige, kategorie-oorstygende Syn van God, die tweede sou van toepassing wees op die syn van God se skepsels, pertinent en onafwendbaar gevestig binne die tien Aristoteliese kategorieë. Wanneer S/syn bedink word, is daar volgens Gent geen ander konklusie moontlik as dat daar geen enkele univokale konsep is wat op beide God en God se skepsels van toepassing gemaak kan word nie, hoewel daar ' $n$ similariteit tussen die twee konsepte bestaan wat ons in staat stel om analogiese stellings oor God te kan maak, waarvolgens God nie net as Syn nie, maar ook attribuutgewys as 'goed', 'vry', 'genadig' en so meer, beskryf kan word.

Skotus (1950:16.266) vind hierdie Gentiaanse middeweg prinsipieel onwerkbaar: indien ons werk met eenvoudige konsepte wat nie uit samestellende onderdele bestaan nie, kan daar nie iets wees soos die betekenis van ' $n$ woord wat gedeeltelik dieselfde is as en gedeeltelik verskil van ander woorde nie. Indien die konsepte wat ons op God van toepassing maak ekwivokaal is, met ander woorde, verander in betekenis die oomblik wanneer dit van toepassing gemaak word op God se skepsels, is daar geen wyse waarop eienskappe van God gekonkludeer kan word vanuit die eienskappe van God se skepsels nie. Meer logikaal-tegnies: enige poging om 'n analogiese predikaat as die middelterm van 'n sillogisme te gebruik, is sodanig skuldig aan hierdie Skoties-benoemde 'flater van ekwivokaliteit' (Skotus 1950:16.266). 'n Konsep is volgens Skotus (1950:3.18) univokaal of 'n univocatio wanneer dit oor ' $n$ sodanige intrinsieke eenheid beskik dat enige poging om enige eienskap daarvan terselfdertyd te affirmeer en te negeer, noodsaaklik op 'n kontradiksie moet aankom: daarom het die betrokke konsep genoegsame intrinsieke eenheid dat dit as ' $n$ middelterm van 'n sillogisme kan dien en wanneer twee pole dan verenig word deur 'n univokale

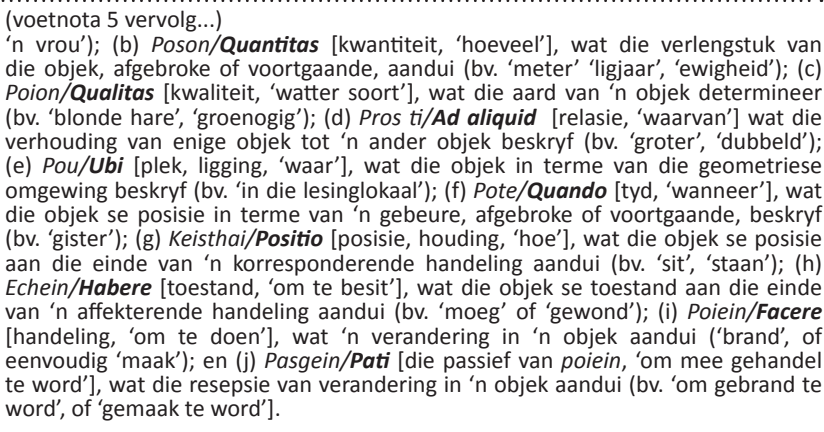

begrip in hierdie sin van die woord, aanvaar kan word dat die twee pole inderdaad in betekenis verenig is.

Skotus het natuurlik hiermee in oog dat daar ' $\mathrm{n}$ univocatio van syn is wat van toepassing op sowel God as God se skepsels is: indien met sekerheid gestel kan word dat $a=b$, maar getwyfel word of $a=c$, dan moet $b$ en $c$ verskillende konsepte wees. Indien 'n mens met sekerheid kan stel dat God syn is, maar nogtans twyfel of God 'n oneindige of eindige entiteit is, dui dit aan dat die konsep syn modaalmatig verskil in terme van oneindige syn en eindige syn en dat syn dus ' $n$ univokale konsep is, wat ten aansien van beide die oneindige en eindige in dieselfde sin van die woord betekenis dra (Skotus 1950:3.29). Ook ander konsepte buiten syn, soos 'die goeie', is vir Skotus transendentaal in die sin dat dit nie net die grense van die praedicamenta transendeer nie, maar inderdaad ook die verskil of gaping tussen oneindigheid en eindigheid transendeer.

Skotus se argument is dus: (1) ek kan nie seker wees van en twyfel aan een en dieselfde konsep nie; (2) ek kan seker wees dat God syn is, maar twyfel of dit oneindige of eindige syn is; (3) dus, die konsep van syn is nie dieselfde as die konsep van oneindige of eindige syn nie; (4) daar is dus 'n konsep van syn wat verskil van oneindige of eindige syn (maar tog gemeen is aan beide). Skotus se argument beweeg gevaarlik naby aan die berugte 'flater van die gemaskerde man' ('Ek ken my pa maar ek ken nie die gemaskerde man nie, dus is die gemaskerde man nie my pa nie'), maar is desnieteenstaande deur Skotus as die sterkste teoretiese posisie ten opsigte van die polemiek tussen analogiese ekwivokaliteit en univokaliteit beskou.

Skotus moet nie misverstaan word nie: hy ontken nie dat daar konsepte is wat inderdaad analogies tussen God en God se skepsel opereer nie. Wat hy wel beweer, is dat sodanige analogiese konsepte gebaseer is op en nie sou kon bestaan sonder eenvoudige univokale konsepte nie. Skotus (1950:3.26-29) argumenteer byvoorbeeld dat die formele konsep 'intellek' eerstens, absoluut en fundamenteel ten opsigte van sigself geld. Omdat die konsep sigself geen formele tekortkominge of begrensing aandui nie, word enige tekortkominge in die begrip eers wanneer dit op God se skepsels van toepassing gemaak word, sigbaar. Wanneer die begrip op God van toepassing gemaak word, word geen tekortkominge sigbaar nie. Enige vraag of ondersoek na God moet volgens Skotus gebaseer wees op die aanname dat 'intellek' dieselfde univokale konsep onderhou waarvan die tekortkominge by mense sigbaar is. Wanneer ons die begrip 'intellek' op God van toepassing maak, begin ons nie met 'n nuwe taalles nie. Dit is dieselfde konsep. ${ }^{6}$

6.Of S/syn analogies-ekwivokaal of univokaal is, bly ook na skotus problematies as gevolg van die algemene vaagheid van die Middeleeuse opvatting van syn. Dit is nie die probleme wat Skotus ten opsigte van die Genties-Aquiniese posisie ten opsigte van analogiese ekwivokaliteit opper wat die probleem aksentueer nie, maar die probleem van syn as sodanig, soos wat Hegel (in terme van Ockhamiaanse stemming van die schlechte Undendlichkeit) en Heidegger (in terme van die Skotiaanse Grammatica Speculativa in sy doktorale proefskrif) eeue later in hulle krities-waarderende aansluitings by onderskeidelik Willem van Ockham en Skotus, sou benadruk. Indien ons van 'bestaan' sou wou praat en dit tot uitdrukking sou wou bring in ' $n$ sin soos 'daar is ' $n$ God', word die vrag of die syn tersprake sou wou bring in ' $n$ sin soos 'daar is " $n$ God, word die vraag of die syn tersprake 'ben' 'bestaan'nie 'n predikaat-subjek verhouding konstitueer nie. Vir Skotus is 'bestaan' 'n ' 'bestaan', 'syn', 'om te wees', baie duidelk univokaal. Gestel daar sou in die heela net drie objekte wees, $s, p$ en $r$. Die predikaat '... is of $p$ of $r$ of $s^{\prime}$ sou dan presies in dieselfde en gelyke mate tot elkeen van die drie objekte verbind moes word. 
Skotus se univocatio is ' $\mathrm{n}$ uitstekende voorbeeld van hoe taalbegrip en logika as 'n samehangende probleemstelling in die Middeleeue funksioneer: sy hele argument en teoretiese posisie staan en val by 'n opvatting van 'n noue samehang tussen taal en logika. Dit was egter ook 'n invloedryke en gevolgryke posisie vir die deeldissipline van formele logika as sodanig - hoewel Skotus homself nie as ' $n$ formele logikus aangebied het nie. Skotus se modaal-univokale posisie gee eerder aanleiding tot die ontwikkeling van ' $n$ alternatief op die terministiese logika, wat veral via die Parysiaanse dosent Willem van Sherwood en die veel minder bekende Petrus Hispanus (kyk Beukes 2011b:7) as die gangbare logikale posisie in die laat $13 \mathrm{de}$ eeu gevestig is. Vanuit Skotus se werk word 'n modistiese logika ontwikkel, wat nie soos die terministiese logika fokus op die eienskappe van individuele terme nie, maar eerder fokus op meer algemene taalkundige kategorieë soos selfstandige naamwoorde, werkwoorde, naamvalle en temporele aanduidings, daarom 'n modi significandi, die studie van die wyses van verwysing. Die modistiese posisie in terme van die konstellasie taalbegrip-logika is dat betekenis op klanke oorgedra word deur ' $\mathrm{n}$ menslike konvensie, wat impositio genoem is. Die eenheidselement van betekenis is dictio genoem. 'n Enkele dictio of betekenisstigtende eenheidselement mag verskeie verbale vorme ondervang: die naamvalle van 'n selfstandige naamwoord in Latyn, plus enige byvoeglike naamwoorde en bywoorde wat daarmee geassosieer word (vgl. Kenny 2005:142). Een van die modiste se voorbeelde by voorkeur was die dictio vir pyn (juis omdat 'n mens nooit kan onthou hoe pyn 'voel' nie), wat insluit die selfstandige naamwoord dolor in die verskeie naamvalle, die werkwoord vir pyn (doleo) en die bywoord geassosieer met pyn, 'pynigend' (dolenter): die basiese konvensie wat oorgedra word op die sensasie van pyn is die eerste impositio benoem, terwyl verdere konvensies, deur 'n opvolgende impositio, die modi significandi van dolor, doleo, dolenter beslag gee. Sommige modi significandi is wel gereken as meer wesenlik as ander: komplekse operatiewe stelreëls is in die 14de eeuse skolastiek geformuleer aan die hand waarvan ' $n$ bepaalde taalhandeling, soos die konstruksie van 'n selfstandige naamwoord of werkwoord, as meer wesenlik geag behoort te word in die konstruksie van 'n koherente sin, as wat met 'n naamval of bywoord die geval sou wees. Die modi significandi is dus, om die moderne begrip te gebruik, as tweede impositio meerendeels sintakties in oriëntasie. Die eerste impositio, ratio significandi genoem, is meerendeels semanties in oriëntasie. Die feit dat die eerste impositio semanties is, beteken nie dat Skotus se modistieslogikale eksponente 'n semantiese element wou isoleer wat met die modi van verwysing sou moes korrrespondeer nie. Die ervaring aan 'taalhandeling' is juis 'n modale, binneontleende onderskeid (en Skotiaanse gemeenheid) tussen ratio en modi. Hierdie modale betekenis stel ons in staat om 'n 'formele betekenis' te vind, wat weliswaar geleksikaliseer kan woord, ' $n$ betekenis dus vanuit 'die deug van taal' (virtus sermonis) wat in 'n woordeboek omskryf kan word.
Maar hierdie modale betekenis wil juis andersom ook die geleefde, nie-leksikale betekenis van die woord ondervang (vgl. Kenny 2005:143): Die sin 'Homo appropinquat' byvoorbeeld, bestaan op grond van die virtus sermonis uit die nominatief enkel manlike selfstandige naamwoord Homo, wat 'manspersoon' beteken, asook die derde persoon enkelvoud van die werkwoord appropinquo, wat 'naderkom' beteken, dus "n man kom nader'. Maar wanneer ons sou vra watter man dit is wat naderkom, ervaar die modistiese posisie moeite om uit die allure van taaldeugdelikheid te ontsnap en word ' $n$ terministiese ingrepe nogeens onafwendbaar. Hierdie onafwendbaarheid is deur die helderste teoretikus van die 14de eeuse skolastiek ingesien: Willem van Ockham, wat die terministiese logika op geniale wyse van die Skotiaans-modistiese interval sou rehabiliteer.

\section{Willem van Ockham: Intentio animae, per medium ex/intrinsecum}

Willem van Ockham bied ' $n$ alternatief op die AquiniesGentiese (analogies-ekwivokale) en Skotiaanse (modistiesunivokale) posisies, naamlik 'n nominalisties-terministiese en dus nie-realistiese konstellasie van taalbegrip en logika. Hierdie alternatief sou reeds vroeg in Ockham se loopbaan geassosieer word met die afloop van die via antiqua en die opkoms van ' $n$ hele domein van nuwe moontlikhede in die filosofie en teologie, die via moderna. Hierdie terministiese alternatief is nie de novo oorspronklik nie, maar weliswaar die kulminasie van eeue - inderdaad sedert Augustinus en Boethius - se grondige analises van woorde, sinne, terme en proposisies in die poging om koherent oor die werklikheid te kan praat (vgl. Leff 1975:14 e.v.), die hele erfenis van wat in hierdie artikels as die 'konstellasie' van taalbegrip en logika in die Middeleeuse filosofie genoem is. Die via moderna bring die tradisie van die skolastiese filosofie, veral soos gemanifesteer in Aquinas en Skotus, tot 'n einde in die sin dat Ockham talle van die skolastiek se fundamentele premisses aanval en effektief ondermyn (vgl. Gilbert 1974:86).

Willem van Ockham is gebore circa 1285 te Ockham, Surrey. As jong Franciskaanse bedelmonnik het sy studies te Oxford in 1309 begin, waar hy ook vanaf 1315 kurrikulumgewys soos alle Middeleeuse dosente na Abelardus - oor Lombardus se Sententiae begin doseer het, maar as gevolg van interne akademiese, kerklike politiek en 'n briljante dog onvoltooide proefskrif, nooit professor - magister actu regens - sou word nie en vir die res van sy lewe die ironiese bynaam Venerabilis Incepto ('merkwaardige beginner') sou dra: ironies, omdat sy nalatenskap die volle 14 de eeuse register in logika, filosofiese teologie, politieke teorie en fisika gesaghebbend en uiters krities bestryk (vgl. Goddu 1984:11 e.v.). ${ }^{7} \mathrm{Hy}$ is in sowel die eietydse analitiese filosofie as die Middeleeuse nisnavorsing uiters deeglik gekommentarieer, met 'n lys van sekondêre literatuur wat in geheel onoorsigtelik geword

7.Ockham word bykomend ironies by Oxford steeds gereken as onder die beroemdstes van haar graduandi, met inbegrip van voorgangers, tydgenote en nabye opvolgers soos Bredon, Bacon, Erasmus, Locke, Donne, Wesley, Hobbes, Toynbee, Eliot en baie later, Stephen Hawking (vgl. Oxford 2011). 
het (vgl. Beckmann 1992:2; Heynick 1950:164-183; Reilly 1968:197-214). ${ }^{8}$

Indien ons die uiteensetting van die verhouding taalbegriplogika by Abelardus in oog hou, soos uiteengesit in die eerste artikel (Beukes 2011b), word dit duidelik dat Ockham teruggryp na die Abelardiese voor-skolastiek om 'n houdbare kritiek teen die analogies-ekwivokale en modistiesunivokale skolastiese posisies op te stel (vgl. Marenbon 2007:7586 e.v.). Beide Abelardus ${ }^{9}$ en Ockham posisioneer hulle metafisika dialekties-nominalisties en soos Abelardus handhaaf Ockham die posisie dat alle dinge partikulier is en stuur daarmee 'n duidelike verset teen universalisme of die moontlikheid dat enige werklikheid in byvoorbeeld 'n getal kan bestaan, van stapel. Ockham was minder dialekties en fermer nominalisties as Abelardus: Ockham ontken blindweg die bestaan van metafisiese universeles, beklemtoon die redusering van ontologie tot die absolute minimum, of ontologiese parsimonie (Ockham se beroemde 'skeermesbeginsel': 'moet geen entiteit vermenigvuldig tensy absoluut noodsaaklik nie, skeer eerder af'), en ontken kategories die algemene bestaan van abstraksies, soos in wiskundige of kwantitatiewe entiteite (vgl. Tweedale 1992:432).

Ockham se nominaliserende induksie van die meer dialektiese Abelardus bring hom tot 'n volstrek terministies-nominalistiese posisie: alle tekens be-teken (of 'verteenwoordig') individuele dinge in die werklikheid, omdat daar geen universele dinge in die werklikheid bestaan

8.'n Oorsig van die vermeldingwaardigste monografiese werk en skopusbeperkte analises wat oor Ockham die afgelope dekades gedoen is, behoort in te sluit Adams ([1987] - 'n weergalose, twee-volume inleiding tot Ockham se lewe en filosofie), Ashworth en Spade (1992), Goddu (1984), Hirvonen (2004), Hudson en Wilks (1987), Leff ([1958] - laaste drie hoofstukke, 1975 in geheel), Leppin (2003), Maure (1999), Spade $(1980,1995,1999,2006)$, Tauchau (1988) en die voortreflike werk van Tweedale (1992). Hoewel betreklik gedateerd, kan ook die standaardkommentaa van Moody (1935) nie oorgesien word nie. Ten opsigte van die konstellasie taalbegrip-logika as sodanig, kyk in besonder die resente bloemlesing van Bosley en Tweedale (2004:301-310, 335-337, 419-436) en daarby die uitstaande seleksies en kommentare in Copleston (1972:236-256), Kenny (2005:143-150), Luscombe en kommentare in Copleston (1972:236-256), Kenny (2005:143-150), Luscomb (2004:133-158) en Marenbon (2007:7547-7727). Soos met die geval van die eerste en tematiese geleiers asook seleksie-skopus vir die onderhawige navorsing oor Ockham se hantering van die saak.

9.Onoortuigd deur die uiteenlopende teoretiese posisies van beide sy twee vroegste leermeesters, die nominalis Roskelin en die realis Willem van Champeaux, bepleit die 12de eeuse Abelardus (1919:25 e.v.) 'n dialektiese middeweg tussen nominalisme en realisme. Enersyds beskou Abelardus die nominalistiese posisie as absurd: om te beweer dat Johannes en Paulus niks in gemeen het buiten die naam of noemer 'mens' nie, terwyl die noemer op elkeen betrekking geniet juis op sterkte van objektiewe ooreenkomste, is 'n logies onhoudbare posisie. Andersyds is dit ewe problematies om na die aanspraak van die realistiese posisie te beweer dat daar 'n substansie-entititeit, in hierdie geval die spesie homo sapiens, is, wat volledig teenwoordig is in een en elke individu: dit sou beteken dat Johannes volledig identies teenwoordig is in een en elke individu: dit sou beteken dat Johannes volledig identies aan Paulus is en op twee plekke gelyktydig sou moes wees. ' $n$ Ooreenkoms tussen mense is nie iets substansieels of partikulier soos ' $n$ mens nie, terwyl slegs ' $n$ mens, individuele, partikuliere mense bestaan: "Wanneer ons byvoorbeeld beweer dat die ooreenkoms tussen mense nie self' $n$ mens is nie, moet ons dit vermy om voor te gee dat daar geen ooreenkoms is nie, omdat ons inderwaarheid wil beweer da die een met die ander ooreenkom - en dit is tog nie self weer ' $n$ mens nie, maar ' $n$ status, ' $n$ toepassing van die begrip 'mens' op die partikuliere individu' - (Abelardus 1919:20). Beide nominalisme en realisme val volgens Abelardus (1919:28) terug op 'n ontoereikende analise van wat dit beteken dat 'n woord 'beteken' of 'verwys'. Woorde verwys op twee wyses: woorde be-teken dinge en woorde ver-woord idees. Woorde be-teken dinge juis deur die gepaste idees konseptueel op te roep, daardie konsepte waarmee die verstand die 'dinge in die wêreld bring' (Abelardus 1919:32). Ons eien ons hierdie konsepte toe deur telkens mentale beelde te oorweeg, wat nie gewone beelde is nie. Dit is hierdie konseptuele oorweging van mentale beelde wat ons in staat stel om woorde dinge te laat be-teken en wat klanke betekenisvolle woorde lat word. Daar is ceen 'universele mens' los van die universele noemer 'meorde laat word. Daar is geen 'universele mens' los van die universele noemer 'mens' nie - nominalisme is korrek in daardie opsig. Maar die noemer 'mens' is ook nie sonder betekenis nie: dit word in die verstand verbeeld deur ons verstaan in ' $n$ beeld vorm (van in ' $n$ beeld vormeer, vormeer ons verbeeldende intellek ' $n$ woord vanuit ' $n$ klank. Daarom is universeles 'intellektuele skeppings, niks meer of minder nie' (Abelardus 1919:522). wat deur tekens be-teken kan word nie (vgl. Kenny 2005:144). Ockham (1967:115 e.v.) bied 'n hele reeks metafisiese argumente aan teen die opvatting dat 'n universele 'n algemene en natuurlike werklikheid is wat hoegenaamd in individuele dinge teenwoordig is: onder meer, dat indien individuele dinge universeles bevat, sou geen individuele ding ex nihilo geskep kon word nie, aangesien die universele deel of onderdeel daarvan reeds sou bestaan het voordat die skepping van die individuele ding sou kon plaasvind; of, indien God 'n individuele ding sou vernietig, God daarmee saam alle ander individuele dinge van (minstens) dieselfde species sou vernietig omdat iets algemeen en natuurlik aan die species se bestaan vernietig sou word. 'n Universele is volgens Ockham $(1967: 1,12)$ altyd reeds 'n singuliere en is 'n 'universele' slegs op sterkte van die be-tekening van daardie singuliere kwaliteit, wat 'n be-tekening is deur 'n teken (wat baie ander dinge kan be-teken).

Dit is juis in sy onderskeid van twee soorte universeles wat Ockham $(1967: 1,12)$ se afhanklikheid van Abelardus weer oproep: Ockham differensieer naamlik tussen natuurlike en konvensionele universeles. ' $n$ Natuurlike universele is ' $n$ gedagte in die verstand, inderdaad, om Abelardus (1919:28) se begrip te gebruik, ' $n$ 'mentale beeld', intentio animae, terwyl 'n konvensionele universele universeel is omdat dit deur konvensie so aanvaar word: in woorde, dus in geskrewe en (hoewel gesubordineerd aan) gesproke taal. Beide natuurlike en konvensionele universeles word gevorm wanneer mentale beelde saamgevoeg word om mentale proposisies te vorm, net soos wat gesproke tekens saamgevoeg word om hoorbare, koherente proposisies te vorm. Hierdie mentale beelde, intentio animae, vorm ' $\mathrm{n}$ taalsisteem wat Ockham uniek en sonderling 'mentale taal' noem. Afgesien van die gesproke, konvensionele tale soos Latyn, Duits en Engels, deel alle mense hierdie algemene, natuurlike taal, soos gemanifesteer in byvoorbeeld handgebare - 'n diep gevestigde opvatting in die Middeleeuse filosofie sedert Augustinus. ${ }^{10}$ Dit is vanuit hierdie natuurlike universaliteit van intentio animae in die 'mentale taal' dat verskillende tale beslag kry en elkeen afsonderlik betekenis kan oordra (vgl. Kenny 2005:145; Marenbon 2007:7588 e.v.).

Intentio animae as mentale taal bevat volgens Ockham (1967:1.14) sommige van die grammatikale eienskappe wat so nougeset in die Skotiaanse modisme uitgewys is, maar nie almal daarvan nie: mentale taal bevat selfstandige naamwoorde en werkwoorde, maar nie voornaamwoorde en deelwoorde nie. Selfstandige naamwoorde (in Latyn) het ook in die mentale taal wel een tot ses naamvalle, maar niks meer nie; dit is in die 'mentaliteit van taal' gestroop tot

10.Vergelyk Beukes (2011b:2): Die opstel van taalkundige konvensies vooronderstel vir Augustinus ' $n$ gemeensaamheid of uniformiteit tussen mense in hulle natuurlike, voorkonvensionele reaksies met betrekking tot byvoorbeeld handgebare 'die natuurlike taal van alle mense' (Augustinus 1992:I.8.13). Die taalkundigostensiewe definisie van ' $n$ ' $w o o r d$ ' aan die hand van voorbeelde sal 'n kind nie die betekenis van die 'woord' leer nie: 'n kind moet 'die woord herhaaldelik hoor soos dit korrek in behoorlike sinskonstruksies gebruik (word)' (Augustinus 1992.1.8.13). pie leerproses word begin deur die kind se eie pogings om sy eie warnemings, Die leerproses word begin deur die kind se eie pogings om sy eie waarnemings, sensasies en behoeftes voor-taalkundig tot uitdrukking te bring: dit is egter juis tekenend) te praat, dat die leerproses momentum kry. Augustinus (1992:I.8.13) maak in hierdie verband ' $n$ stelling wat deurlopend in die Middeleeue beklemtoon is, naamlik dat 'woorde gekonnekteer is met die primitiewe, die natuurlike, die uitdrukking van sensasie.' 
uiterste skaarsste. Indien twee uitdrukkings in Latyn, of selfs twee uitdrukkings in twee verskillende tale sinoniem is, sal die twee uitdrukkings net met een element in die mentale taal korrespondeer. Daar is met ander woorde nie iets soos 'sinonimiteit' in die mentale taal nie. Die terme van die mentale taal is konsepte en die proposisies van die mentale taal is mentale oordele. Waar die be-tekening van terme in konvensionele tale inderdaad konvensioneel en veranderlik is - in Latyn is canis, 'hond' in Afrikaans en 'dog' in Engels - is die be-tekening van terme of eerder konsepte in die mentale taal afgeslote en eenduidig. Dit is hierdie afgeslote eenduidigheid wat Ockham se ontologiese parsimonie of 'skeermesbeginsel' binne die konteks van logika en taalbegrip ten beste komplementeer.

Binne die formele logika staan die poging om selfs meer as die 'absolute noodsaaklike' weg te skeer, waar daar met ander woorde geen potensiaal hoegenaamd vir ambivalensie en ekwivokaliteit is nie, voorop te stel. Laat-skolastiese en vroeg-moderne logika wemel van voorbeelde waarin gepoog word om aspekte van natuurlike taal te idealiseer, veral met gebruikmaking van klein verbindinge soos 'en', 'of', 'alle' en so meer, juis omdat dit die kwantifisering van konvensionele taal in suiwer logiese taal (inderdaad wiskundig) wil bemoontlik. Ockham (1967:1.19) maan egter teen hierdie poging om formele logika in natuurlike taal te wil vertaal: om ' $n$ 'ideale taal' vir die doeleindes van 'n logiese argument op te stel wat juis die doel het om tekortkominge en ambivalensies in natuurlike taal te identifiseer, is uiteraard houdbaar; om egter daarvanuit te impliseer dat so 'n 'ideale taal' reeds aanwesig in die alledaagse gebruik van natuurlike taal, wat ook die hoogste verklaringspotensiaal vir natuurlike taal bevat, is, sou die mentale taal subordineer aan sodanige 'ideale taal' en is daarom vir Ockham radikaal onhoudbaar.

Juis om hierdie voortdurende pogings vanuit die formele logika om 'n 'ideale taal' op te stel te weerstaan, wysig Ockham die teorie van suppositio, wat in die vorige artikel (Beukes 2011b:7) onder die afdeling 'Petrus Hispanus: significatio, suppositio' bespreek is: Hispanus (1971:81) noem die mees basiese suppositio 'natuurlike suppositio', waarmee die kapasiteit van enige term wat significatio het om vir enige saak waarop die term van toepassing gemaak kan word, as't ware 'in te staan', wat ook die letterlike betekenis van die Latynse woord suppositio is. Die wyse waarop hierdie kapasiteit in verskillende kontekste aangewend en uitgeoefen word, gee aanleiding tot verskillende vorme van suppositio. Naas 'natuurlike suppositio' onderskei Hispanus (1971:81) verder ook 'n 'eenvoudige suppositio' van 'n 'persoonlike suppositio': die afwesigheid van 'n bepaalde of onbepaalde lidwoord konstitueer ' $\mathrm{n}$ eenvoudige suppositio: 'mense is sterflik' verskil in die eenvoud van die bepaaldheid van die persoonlike suppositio " $\mathrm{n}$ mens klop aan die deur'. ${ }^{11}$

11.Hispanus (1971:88 e.v.) onderskei gevolglik drie verskillende wyses waarop " woord subjekvervanging in ' $n$ sin moontlik kan makk, wat korrespondeer met diskrete, gedetermineerde en distributiewe suppositio. In die sin 'Die hond het pas gedrink' is die woord 'hond' ' $n$ diskrete suppositio: die predikaat is gebonde aan gedrink' is die woord 'hond' 'n diskrete suppositio: die predikaat is gebonde aan $n$ pertinent enkele een van items waarvoor die term 'hond' gebruik kan word.
Hierdie soort suppositio is gebonde aan eiename, aanwysende voornaamwoorde en beskrywings. By gedetermineerde suppositio, soos " $n$ Hond krap aan die deur', heg die predikaat aan een spesifieke saak waarop die term 'hond' betrekking het,
maar spesifiseer dit nie verder nie. By distributiewe suppositio, soos "n Hond het
Ockham (1967:1.60) wysig eenvoudige suppositio egter om na 'n mentale entiteit te verwys: nie bloot 'mense is sterflik' nie, maar eerder byvoorbeeld 'mense is 'n species', wat nie bloot na alle individuele mense verwys nie, maar na 'n mentale term van die enigste soort ding wat so 'n soort species kan wees. Wat persoonlike suppositio betref, handhaaf Ockham die wesenlike van die bepaaldheid van die verwysing, dat die term staan vir wat dit beteken, 'n betrokke, spesifieke mens wat aan 'n betrokke, spesifieke deur klop. Maar Ockham voeg daarby die onderskeid dat persoonlike suppositio kan funksioneer selfs waar die term nie staan vir iets in die werklikheid as sodanig nie. Persoonlike suppositio word dan verstaan synde waar 'n term staan vir dit wat dit be-teken, of dit 'n buite-mentale werklikheid is, of 'n woord, of 'n mentale konsep, of 'n teks, of wat ook al 'dinkbaar en verbeelbaar' is (Ockham 1967:1.64; vgl. Kenny 2005:147; Luscombe 2004:148). Die wysiging deur Ockham is strategies: hy wil persoonlike suppositio as die mees geparsde, 'Ockham-geskeerde' taalvorm gebruik wat op sowel subjekte as predikate van toepassing gemaak kan word. So kan 'n predikaat be-teken en 'instaan-vir' waarvan dit ook al waar is. Indien Petrus, Paulus en Johannes die enigste mans is wat bestaan, dan moet die stellings 'elke man is sterflik' en 'elke apostel is 'n man' die woord 'man' voorbehou as 'n persoonlike suppositio: die eerste sin is dan ekwivalent aan 'Petrus, Paulus en Johannes is sterflik' en die tweede sin ekwivalent aan 'elke apostel is of Petrus of Paulus of Johannes'. Daarom is Ockham se posisie ook terministies: enige algemene term behels onmiddellik en wesenlik 'n verkorte lys van eiename.

Vanuit sy terministies-nominalistiese en persoonliksuppositiese posisies, begin Ockham skerper op die verhouding taalbegrip-logika fokus: 'n proposisie soos 'Jesaja is ' $n$ mens' is waar en alleen noodsaaklik waar indien die subjekterm 'Jesaja' en predikaatterm 'mens' vir een en dieselfde saak staan. Dit is 'n goeie voorbeeld van wat die baie ou en bekende 'twee-naam waarheidsteorie' behels: 'n affirmatiewe kategoriese proposisie is waar wanneer dit 'n subjek en 'n predikaat verbind as twee name van dieselfde saak (vgl. Kenny 2005:148; Luscombe 2004:149; Marenbon 2007:7659). Maar Ockham se posisie is meer gesofistikeerd, juis omdat hy skerper verparsend en terministies op die proposisie wil inspeel. Indien 'Jesaja is 'n profeet' waar is omdatJesaja sowel'Jesaja' as 'profeet' genoem kan word, word dit onmoontlik om te verduidelik wat die waarheidsgehalte van die proposisie 'Jesaja is nie 'n leeu nie' sou wees. Om te weet dat 'leeu' nie 'n naam-vir of eienaam vir Jesaja is nie, moet ons weet waarvoor 'leeu' wel 'n naam is en bly ons in gebreke om te antwoord watter 'leeu' dit is wat Jesaja nie is

\footnotetext{
(voetnota 11 vervolg...)

vier pote', heg die predikaat aan alles waarop die term 'hond' betrekking het. Gedetermineerde suppositio kan van distributiewe suppositio onderskei word deur byvoorbeeld te vra, 'watter hond?'. Indien die vraag betekenisvol beantwoord kan word, het ons te doen met gedetermineerde suppositio. Maar daarby stel Hispanus (1971:82) dat ' $n$ woord nie alleen persoonlike suppositio kan voorbehou wannee dit in die subjekplek geplaas word nie, maar ook wanneer dit as ' $n$ predikaat funksioneer: dit is wat 'verwarrende suppositio' beteken. In 'Steffi is ' $n$ wolfhond' (of "n wolfhond is ' $n$ hond') is die suppositio van dio term 'hond' verwarrend, (of " $\mathrm{n}$ wolfhond is 'n 'vond') is die suppositio van die term 'hond' verwarrend, in die sin dat dit, net soos met distributiewe suppositio, nie betekenisvol is om ' vra 'watter hond?' "natuurlik' is formele suppositio, teenoor gematerialiseerde suppositio. Die onderliggende idee aan hierdie onderskeid is dat die klank van 'n woord die woord materialiseer terwyl betekenis in die vorm van die woord gevind moet word.
} 
nie. Ockham se posisie bemoontlik 'n uitkoms: die lys van moontlike eiename vir 'leeu' en die een-item eienaam lys vir 'Jesaja' het geen gemene term nie. Maar ook hierdie antwoord bied nie vir die parsende Ockham 'n adekwate uitkoms nie en skep trouens 'n (kousaliteits-)deterministiese probleem: indien elke algemene term wesenlik 'n verkorte lys van eiename behels, moet elke proposisie óf noodwendig waar óf noodsaaklik vals wees: 'Jesaja is 'n mens' word sekerlik nie as ' $n$ identiteitstelling vir Jesaja aangebied nie, maar dit is presies wat gebeur indien dit beteken dat 'Jesaja is of Jesaja of Jeremia of Maleagi'. Dit is dus die logiese verhouding tussen verskillende proposisies wat hiermee in spel gebring word.

Om hierdie logiese verhouding te ondervang, rehabiliteer Ockham die teorie van consequentiae vanuit die logica vetus, reeds ontwikkel by Boethius (Beukes 2011b:6): Boethius (1978:45 e.v.) maak ' $n$ belangrike onderskeid tussen twee soort hipotetiese stellings. Eerstens ontwikkel hy die begrip consequentia as ' $\mathrm{n}$ aanduiding van ' $\mathrm{n}$ 'outentieke hipotetiese stelling' - een waarvan die waarheid aldan nie, uiteindelik sal moet manifesteer. Dan argumenteer Boethius dat sommige consequentiae geen noodwendige verbintenis tussen die antesedent en die consequentia of gevolg daarvan aandui nie. Ander consequentiae weer, volg noodwendig vanuit die antesedent. Boethius (1978:61 e.v.) stel vanuit hierdie onderskeid dan 'n taalanalitiese proposisiekritiek op: ware consequentia, in beide gevalle, kan afgelei word vanuit 'n sisteem van superieure universele proposisies, wat Boethius loci noem. Hierdie loci stel ons in staat om die (gestruktureerde) waarheid aangaande enige proposisie te begryp. ' $\mathrm{n}$ Taalhandeling, naamlik die beskrywing van die loci, wat Boethius (1978:64 e.v.) uiters gedetailleerd uitwerk, word dus die meehanger van logiese analise. Sowel taalbegrip as logiese analise speel ' $n$ rol in die herkennning van die waarheidsaanspraak van ' $n$ proposisie.

Uiteraard staan Ockham radikaal skepties en afwysend teenoor die moontlikheid van sodanige universele loci. $\mathrm{Na}$ Boethius tree die opvatting van consequentia as ' $\mathrm{n}$ voorwaardelike proposisie in die vroeg-skolastiek sterker na vore (vgl. Kenny 2005:149): 'indien Jesaja 'n mens is, is Jesaja ' $\mathrm{n}$ dier', waar 'Jesaja is ' $\mathrm{n}$ mens' die antesedent en 'Jesaja is ' $\mathrm{n}$ dier' die gevolg is. So verstaan is consequentiae waar of vals en noodsaaklik of kontingent. Hiervanuit kan 'n argument gekonstrueer word: 'Jesaja is ' $n$ mens. Dus, Jesaja is 'n dier'. Hier is dan nie een nie, maar twee proposisies, waar die antesendent as premisse funksioneer en die gevolg ' $n$ gevolgtrekking word. Argumente is nie soos voorwaardelike proposisies bloot waar of vals en noodsaaklik of kontingent nie. Argumente is sterk of swak, geldig of ongeldig, afhangende daarvan of die gevolg vanuit die premisse funksioneer of nie. Dit is presies die soort consequentiae wat Ockham in gedagte het: die tref van onderskeid tussen geldige en ongeldige argumente, eerder as die toekenning van waarheidswaarde tussen korresponderende voorwaardelike proposisies.

Ockham (1967:3.3.1) tref eerstens 'n onderskeid tussen 'eenvoudige gevolge' en 'skakelgevolge'. 'n Eenvoudige gevolg word gehandhaaf waar die antesedent nooit waar kan wees tensy die gevolg waar is nie. 'n Skakelgevolg word gehandhaaf waar die antesedent nie tans waar kan wees sonder dat die gevolg waar is nie, hoewel die antesedent op 'n ander tyd waar mag wees sonder die betrokke gevolg.

Tweedens tref Ockham die onderskeid tussen gevolge waarvan die geldigheid intern is oftewel per medium intrinsecum gevolge, en ander gevolge waarvan die geldigheid ekstern is, oftewel per medium extrinsecum gevolge (Marenbon 2007:7708 e.v.; Luscombe 2004:149-153; Kenny 2005:148 e.v.). ' $n$ Gevolg is intern geldig indien die geldigheid daarvan afhanklik is van die betekenis van minstens een van die terme in die premisse of konklusie, byvoorbeeld 'Jesaja hardloop, dus hardloop ' $n$ man' waar die geldigheid afhang daarvan of Jesaja ' $n$ man is. ' $n$ Gevolg is ekstern geldig indien die geldigheid daarvan nie afhanklik is van die betekenis van enige van die terme in die premisse en konklusie nie, waar dit moontlik is om die gevolg skematies met suiwer varieerbares voor te stel, byvoorbeeld: 'indien alle A's B's is, is alle B's A's' (Kenny 2005:149).

Derdens onderskei Ockham (1967:3.3.1) tussen materiële en formele gevolge. Formele gevolge is per medium intrinsecum of per medium extrinsecum geldig. Materiële gevolge, aan die ander kant, handhaaf nie die voorwaarde van die onmoontlikheid van die antesedent se waarheid sonder die waarheid van die gevolg nie en is dus nie aangewese op enige verbinding, intern of ekstern, tussen die inhoud van die antesedent en die inhoud van die gevolg nie. 'n Materiële gevolg vra suiwer na die noodsaaklike valsheid van die antesedent of die noodsaaklike waarheid van die gevolg. Ockham (1967:3.3.1) dui op grond hiervan aan dat 'indien die mens 'n esel is, bestaan God nie' en 'indien 'n man hardloop, bestaan God' beide geldige materiële gevolge is.

Krities belangrik vir die verhouding taalbegrip-logika formuleer Ockham vanuit bogenoemde drie onderskeide dan sy ses beroemde rëels wat na hom tot diep in die moderne (Kenny 2005:150) eerbiedig sou word:

1. Wat vals is, volg nie vanuit wat waar is nie.

2. Wat waar is, mag volg vanuit wat vals is.

3. Wat volg vanuit die gevolg, volg vanuit die antesedent.

4. Wat die antesendent bepaal, bepaal die gevolg.

5. Die kontingente volg nie vanuit die noodsaaklike nie.

6. Die onmoontlike volg nie vanuit die moontlike nie.

Ockham se nominalisme, ontologiese parsimonie en logiese gevolgsonderskeide is reeds in die 14de eeu skerp aangeval. Die vernaamste onmiddellike verset teen Ockham se kenteoretiese aansprake was intiem, juis van ' $n$ ander beroemde Oxonion, wat trouens die bynaam die 'blom van Oxford' gedra het: Johannes Wyclif.

\section{Johannes Wyclif: In res, de universalibus}

Sir Anthony Kenny het enorme waarde tot die Middeleeuse navorsing gevoeg met die publikasie van sy Wyclifmonografie (Kenny 1985), sy vertaling van Wyclif se Tractatus 
de universalibus (Wyclif 1985) en sy redaksionele werk oor Wyclif (Kenny 1986; vgl. ook Hudson \& Wilks 1987:160; Courtenay 1987:92). Die rede vir die waardetoevoeging is dat Wyclif tendensieus in inleidingswerke tot die Middeleeuse filosofie uiters oorsigtelik en skalks hanteer word, of geheel oorgesien word, terwyl klem eerder kerkhistories geplaas word op Wyclif se voor-Reformatoriese kritiek van die Roomse Kerk as op sy inderdaad standhouende kenteoretiese, taalkundig-logiserende posisies. ${ }^{12}$ Wyclif ontbreek ook tipies in bloemlesings tot die Middeleeuse filosofie en skolastiek. ${ }^{13}$ Naas Kenny se grondige herbekendstelling van Wyclif as bona fide Middeleeuse filosoof, is dit net die gedateerde, weer skerper kerkhistoriese hoewel baie volledige werk van Workman (1926) en die kosbare werk van Robson (1961) wat in die skolastiese navorsing werklik gesag dra (vgl. Gilbert 1974:86, 103). Die literatuur is dus alles behalwe onoorsigtelik. Deur Wyclif filosofies behoorlik te isoleer, kontekstualiseer en kommentarieer, word uit die impasse wat deur hierdie ensiklopediese werklikheid geskep is, ontsnap. Ook hierdie artikel, binne die groter rehabiliterende stemming van die projek waarvan dit deel vorm, wil by hierdie rehabilitasie aansluit en hierdie ondergekommentarieerde skolastiese filosoof naas vakbekende figure soos Skotus en Ockham aan die woord bring.

Johannes Wyclif is naby Yorkshire rondom 1328 uit'n gegoede familie gebore en het as jong seun by Oxford begin studeer, waar hy teen 1351 georden was, teen 1356 'n Magister Artium was en teen 1372 'n Magister Theologiae. Hy het tot enkele jare voor sy dood in 1384 by Oxford gebly en gedoseer waar hy as die 'blom van Oxford' besonder eminent gereken was (vgl. Gilbert 174:103). Teen 1381 het sy volgehoue kritiek teen die (uiteraard Katolieke) Kerk se rykdom, eksesse en eksegetiese manipulasies, asook sy verwerping van die leer van transubstansiasie, van hom 'n institusionele buitestaander gemaak. Hy was verantwoordelik vir die vertaling van die Vulgaat in die Engelse moedertaal en 'n inspirasie vir die kontra-Roomse Lollardiese beweging in Engeland, asook vir

12. Uiteraard is Wyclif teologies en kerkhistories baie grondig gekommentarieer, maar nie skolasties-filosofies nie (vgl. Courtenay 1987:88): Vergelyk byvoorbeeld die afwesigheid van 'n grondige Wyclif-bespreking in die andersins gesaghebbende inleiding van Copleston ([1972:259], slegs die een verwysing) - is Wyclif se berugtheid as anti-Roomse, voor-Reformatoriese kampvegter steeds die rede vir sy afwesigheid wanneer ' $n$ Katoliek ' $n$ oorsig tot die skolastiek bied? Strek so ' $n$ polemiek en sensuur inderdaad oor bykans 600 jaar? Vergelyk daarby dan ook die afwesigheid van besprekings van of minstens soliede verwysings na Wyclif in die hiperpresiese Marenbon ([2007:8273], wat wel ander ondergepubliseerde Middeleeuse Oxonians soos Chatton, Bradwardine en Wodeham meer grondig bespreek). Marenbon (2007:8273) gee wel eerlik toe dat Wyclif se nalatenskap eers onlangs filosofies werklik tot reg begin kom ('a complex and in some respects original set of ideas that historians are only now beginning to unravel and assess.') Slegs een verwysing historians are only now beginning to unravel and assess.). Slegs een verwysing na Wyclif is merkbaar in Luscombe (2004:170) se gesaghebbende werk: en dit is werklik tipies. Daarom sou met verwysings na meer as nege uit tien ander inleidingswerk hierdie tendens met redelike gemak uitgewys kon word, naamlik die van Wyclif as buitestaander: as skolastiese filosoof is Wyclif ' $n$ onderwaardeerde figuur wat in weinig inleidingswerke en bloemlesings in die Middeleeuse filosofie aan die bod gebring word. Dit is egter presies die soort figuur waarna hierdie projek op soek is: daar, maar ook nie daar nie, individuele kantaantekeninge by die Middeleeuse filosofie - en juis randfigure vanuit die moderne weergawe van die Middeleeuse filosofie, presies omdat Wyclif in sy eie tyd enorme intellektuele status geniet het, selfs meer as Ockham (vgl. Kenny 1985:146). Tipies modern word hierdie aweregse proto-Hervormer ' $n$ verbygegaande, ' $n$ alleenstaander en 'ondergepubliseerde'. Dit is krities noodsaaklik vir die oorlewing van filosofie as respektabele geestesdissipline dat hierdie soort stem lewendig gehou word in ' $n$ histories-filosofiese polemiek met die epistemologiese eksesse van die sogenaamde 'postmoderne' filosofie (vgl. Beukes 2005:1109 e.v.).

13.Wyclif ontbreek byvoorbeeld volledig in die andersins aweregs-insluitende bloemlesing van Bosley en Tweedale (2004). Feitlik die enigste manier, voor Kenny $(1985,1986)$ se rehabiliterende werke, om enige iets kenteoreties oor Wyclif te kon lees en filosofies iets daaruit te kon ontgin, was om in ' $n$ gestandaardiseerde hon lees en filosofies iets daaruit te kon ontgin, was om in ' $n$ gestandaardiseerde handboek in kerkgeskiedenis
Johannes Hus se pogings tot kerkhervorming en nasionalisme in Bohemië. By die konsilie van Konstans (1414-1418), waar Hus op die brandstapel tereggestel is, is Wyclif se geskrifte formeel verwerp en is hy as ketter verklaar. Daar is toe reeds gefokus op Wyclif as kerkrebel en by sy tegniese akademiese werk grootliks verbygegaan: onder meer sy gesofistikeerde teorie oor hoe sofismes (so genoem na Aristoteles se Sophistici Elenchi), vakterminologies genoem insolubilia - bedrieglike, selfs raaiselagtige sinskonstruksies wat fyn geanaliseer moet word ten einde nie tot absurde konklusies te lei nie in die logica modernorum aangespreek moes word. ${ }^{14}$ Wyclif se interesse was egter pertinent universaliteit en hy het Ockham se kontra-realistiese nominalisme geblameer vir allerlei filosofiese, teologiese en morele dwalinge (Gilbert 1974:108). Die soort realisme wat Wyclif bepleit is egter nie streng Platonies nie, ingevolge waarvan universeles geheel afsonderlik van partikulieres bestaan. Deur aansluiting te vind by ' $n$ onderskeid wat reeds by Abelardus teenwoordig was (Beukes 2011b:6), onderskei Wyclif (1985:3; vgl. Kenny 1986:26 e.v.) verskillende soorte universeles: Universeles in die verstand van God (pre res, 'voor die ding'), universeles as tekens (post res, 'na die ding') en dan die sentrale in res universeles, 'in die ding'. In res universeles is werklik 'in die ding', maar is nie werklik skeibaar van die ding nie, eerder slegs formeel onderskeibaar (vgl. Marenbon 2007:8280). Dit herinner aan Skotus: tog is dinge wat vir Wyclif formeel onderskeibaar is, selfs meer identies as wat dit vir Skotus (na sy pleidooi vir formele onderskeide in Ordinatio, kyk weer supra) is, soortgenootlik dieselfde identiteitsonderskeid wat in die leer oor die Drie-Eenheid aangetref word (Marenbon 2007:8280). Wyclif argumenteer vir hierdie benadering op grond van die redelike konsensuspremisse dat proposisies waar kan wees, en dat een moontlike waar proposisie sou wees dat ' $a$ stem ooreen met $b$ op grond van $c$ '. Deur so 'n proposisie as waar te aanvaar, verstaan ons inderdaad 'n universele - ons verstaan die eenvoud van die ooreenkoms tussen $a, b$ en $c$, op grond van $c$ se $c$-heid wat in $a$ en $b$ aanwesig is, wat ons in staat stel om dit in komplekse vorm as ' $n$ proposisie eweneens te verstaan. Dit is hierdie in res oorweging wat Wyclif ten sterkste van Ockham se nominalisme onderskei (vgl. Gilbert 1974:118): Ockham ontken nie dat daar ooreenkomste tussen partikulieres van dieselfde soort kan wees nie, maar ontken dat hierdie werklikheid 'n universele daarstel.

Wyclif presenteer egter presies die antitese wat deur Ockham ontken word: jy moet universeles of aanvaar (hoewel in res nie werklik onderskeibaar van partikulieres nie), of jy moet ontken dat daar enige grondslag is vir die diep gevestigde onderskeid, minstens sedert Boethius se Aristoteles-resepsie, tussen genera en species. Nie die moedigste skolastikus sou kans sien vir laasgenoemde nie.

Wyclif se posisie kan skerper taalbegripsmatig ook anders gestel word: sy verdediging van die moontlikheid van universaliteit is ' $n$ predikatiewe verdediging van realisme.

14. Byvoorbeeld, die stelling 'ek lieg nou' is vals indien dit waar is en waar indien dit vals is. Die studie van insolubilia bestryk ' $n$ groot deel van die konstellasie dit vals is. Die studie van insolubilia bestryk ' $n$ groot deel van die konstellasie
taalbegrip-logika in die 13 de eeu, maar ook weer na die einde van die 14 de eeu toe (vgl. Gilbert 1974:85-86, 104). 
Die sleutel tot die verstaan van universeles behels ' $n$ verstaan van die aard van predikaatstelling. Die duidelikste vorm van predikaatstelling is waar subjek en predikaat taalkundige terme is, dele van sinne. Trouens, die vraag vir Wyclif is of daar hoegenaamd ' $n$ ander soort predikaatstelling kan wees (moderne logici dink saam met Wyclif nie so nie - vgl. Kenny 2005:151). Wyclif is oortuig dat enige predikaatstelling 'reële predikaatstelling' moet wees: dit dui nie op 'n verhouding tussen terme soos 'Jesaja' en 'woon' in die stelling 'Jesaja woon [in Jerusalem]' nie, maar 'n verhouding tussen werklikhede, naamlik tussen die werklikheid van 'Jesaja' en die werklikheid van (sy) 'woon [in Jerusalem, of wat elders in die werklikheid ook al mag korrespondeer met 'woon'].' Daar moet iets werklik in die werklikheid wees wat met die predikaat 'woon' moet korrespondeer: daarsonder sou daar volgens Wyclif geen onderskeid gemaak kon word tussen waar en vals sinne nie. Sy argument ten gunste van realisme is eenvoudig: enige iemand wat glo in iets soos objektiewe waarheid, is altyd, reeds en by voorbaat verbind tot ' $n$ geloof in reële universeles. Die $a-b-c$ voorbeeld hierbo maak dit duidelik: deur in te sien dat $a$ en $b$ ooreenstem op grond van $c$, kom neer op ' $n$ insig van die universele gemeenheid tussen $a$ en $b$ op grond van die gedeelde $c$-heid van $a$ en $b$.

Enige iemand wat tot ' $\mathrm{n}$ oordeel van soortgenootlikheid in staat is, weet volgens Wyclif wat 'n universele is. Neem die onderskeid tussen tussen genera en species, waarna hierbo verwys is: 'n realis soos Wyclif kan genus eenvoudig definieer as 'dit wat oor die baie dinge wat verskillend in 'n species is, gestel kan word' (Wyclif 1985:3). 'n Nominalis soos Ockham moet op ' $n$ hele swerftog van heromskrywinge gaan, soos dat genus " $\mathrm{n}$ term is wat 'n teorie van praedicabiles' of, die soorte verhoudinge waarin 'n predikaat tot 'n subjek mag staan, onderskryf, of waarvan die teenhanger 'n andersoortige praedicabiles is, of van die baie terme wat dinge be-teken wat spesifiek verskillend is. 'n Nominalis kan nie beweer dat dit wesenlik tot ' $n$ term is dat gepredikeer moet word nie; dalk is daar niemand in die omtrek teenoor wie die term verbaal gepredikeer kan word nie. 'n Nominalis kan ook nie beweer dat enige partikuliere term, 'n partikuliere teken, of klank, of merk, predikeerbaar moet wees nie, omdat geen partikuliere noodwendig is nie; trouens, partikulieres is vlugtig en daarom moet die nominalis dadelik verwys na 'baie terme wat dinge be-teken wat spesifiek verskillend is'. 'n Nominalis kan ook nie beweer dat die term gepredikeer word op grond van 'n term wat 'n verskil in species aandui nie: die woord 'hond' en die woord 'kat' verskil nie in species nie: beide is Afrikaanse selfstandige naamwoorde op hierdie bladsy (vgl. Kenny 2005:152). Daarom moet die nominalis stel dat die terme 'dinge be-teken wat spesifiek verskil'. Maar juis dit is die Achilleshiel van die nominalistiese posisie: deur die spesifieke verskil op die rand te plaas van die ding wat be-teken word, eerder as om die verskil suiwer in die tekens self te vind. Die nominalis skeer nie af nie, maar skep eerder meer werk, sou Wyclif beweer.

Natuurlik werk Wyclif hier met 'n nominalistiese ideaaltipe wat meer ekstreem en ongenuanseerd as Ockham is: die 'terme' in Ockham se sisteem is nie byvoorbeeld klanke of inkmerke op papier nie, maar terme in sy verbeelde mentale taal. Maar Wyclif konfronteer wel Ockham se eiesoortige Achilleshiel: die gebrek aan die eksplisiete verrekening van die verhouding tussen die terme in sy verbeelde mentale taal en die werklike, reële tekens in die werklike, reële werklikheid. Ockham was daarvan oortuig dat hy die funksie en eienskappe van Latynse grammatika effektief kon verduidelik deur ' $n$ mentale teenhanger te postuleer. Wyclif fokus daarop dat die enigste rede waarom die verbeelde mentale taal enige gewaande verduidelikende funksie sou kon voorbehou, is juis omdat dit in die niereële spookagtigheid van die gemoed plaasvind - nie in die reële werklikheid van Wyclif, wat die debat terugforseer na klanke, inkmerke op papier, en vlees en bloed nie.

Allermins is Wyclif ' $n$ teoloog wat filosofiese geleentheidsbelangstellings gekoester het - daardie onderskeid sou eers deur die modern-ensiklopediese dwang van die skeiding tussen teologie en filosofie werklikheid word, met 'n aandrang op uiteenlopende erudisies. Wyclif was 'n eg-Middeleeuse denker, vanselfsprekend sowel bona fide teoloog as bona fide filosoof, die een altyd ongesubordineerd aan die ander. Sy tegniese konfrontasie met Ockham dui op 'n erudisie in en kennis van die volle intellektuele voorgeskiedenis, vanaf Boethius tot by Ockham. Inderdaad, soos Wyclif in die navorsing tot voller herontplooiing kom, sou die aanvoeling dat eerder hy as Ockham die belangrikste grondslae vir die 20ste eeuse taalfilosofie, veral by Wittgenstein, gevestig het, as korrek aangedui kan word (vgl. Kenny 2005:153).

In hierdie opsig is Wyclif tiperend van die soort filosoof wat deur die moderne filosofiese ensiklopedie op grond van idiosinkratiese, sekulariserende oorwegings uitrangeer is tot die marges van die register en waarom Wyclif tot vandag toe nog so 'n ondergepubliseerde, ondergekommentarieerde denker is. Maar dit is juis figure soos Wyclif wat die moderne ensiklopedie se vanselfsprekende integriteit bevraagteken en as subtiele agente vir 'n moderniteitskritiek vanuit die Middeleeue kan funksioneer. ${ }^{15}$

15.Naas Wyclif is daar vele ander sodanige randfigure in die Middeleeuse filosofie, daardie denkers oor wie in inleidingswerke ligvoets beweeg word met ' $n$ enkele verwysing en onnoukeurige, enkelparagraaf resumerings. Middeleeuse filosofie het baie meer om te bied as die moderne hoofstroomseleksie van Augustinus, Lombardus, Anselmus, Abelardus, Aquinas, Skotus en Ockham en, miskien, in inleidingswerke wat verby die Occidenta 作 Avicenna en Averroes. Ons hoef ons ook nien semaak moet word reguit vanaf Ockham anaf die Middeleu na die modern pretendeer word met die tallose verwysings in moderne inleidingswerke na die publikasiedatums van Leviathan of Meditationes nie: baie het na Ockham en tot voor Hobbes en Descartes gebeur, insluitende die produksieperiodes van Nikolaus van Kusa en Marsilius van Padua, twee Middeleeuse denkers op die afgrond voor die moderne, wat in die onmiddellike opvolgartikels in hierdie projek aan die woord gestel sal word. Middeleeuse denkers op die ideehistoriese marges roep fantomies uit die kerkhowe in Engeland, Frankryk, Duitsland, Nederland, Spanje en Turkye om weer gelees te word. So 'n herlesing, waaraan die outeur se lewe gewy is en Deo volente in die jare vorentoe sou kon manifesteer, maar dan saam met De Rivo eers daar wanneer dit manifesteer, sou monnike soos onder meer Adelardus van Bath, Alkuin van York, Berengarus van Turyn, Bertholdus van Moosburg, Blasius van Parma, Thomas Bradwardine, Dietrich van Freiburg Meister Eckhardt, Blasius van Parma, Thomas Bradwardine, Dietrich van Freiburg, Meister Eckhardt, Gerhardus van Cremona, Hendrik van Virneburg, Hugo van Utrecht, Johannes van Jandun, Johannes van Salisbury, Richard Kilvington, Robert Kilwardby, Lambertus en talle ander, kon en wou insluit. 


\section{Petrus de Rivo: Logica tertia}

Binne die konteks van taalbegrip-logika in die Middeleeuse filosofie is daar naas Petrus Hispanus, soos in die eerste artikel (Beukes 2011b:8) aan die woord gebring, 'n ander, selfs minder bekende Petrus: die een wat 'De Rivo' genoem is en verantwoordelik was vir die subtiele oorweging van 'n drieledige logika in die Middeleeuse filosofie, in 'n poging om die spanning wat veroorsaak is deur die SkotusOckham(-Wyclif) ontwikkeling, te ontlont. Die moontlikheid van 'n derde logiese waarde naas 'waar' en 'vals' is gelug in talle debatte rakende Aristoteles se bekende 'see-oorlog metafoor' in De Interpretatione 9, waaronder die hewige debat oor toekomstige kontingentes by Leuven in 1465 .

Reeds Boethius (1877:II, 208.1-4) het geargumenteer dat die Stoïsyne toekomstige kontingentes misverstaan het: as $p$ ' $n$ toekomsverwysde proposisie oor 'n kontingente saak is, is of $p$ of nie- $p$ waar, maar nie $p$ of nie- $p$ hoef noodwendig waar te wees nie. Aristoteles se 'see-oorlog metafoor' lui: 'Of daar is more 'n see-oorlog of daar is more nie 'n see-oorlog nie, is waar', maar nie een van 'daar sal more 'n see-oorlog wees' of 'daar sal more nie 'n see-oorlog wees nie' is vandag noodwendig waar nie. Die Stoïsyne se historiese opvatting dat Aristoteles sou bedoel het dat sulke toekomstige kontingentes nie waar of vals is nie, is misplaas, omdat dit by die begrip 'nie noodwendig waar nie', verbygaan. Boethius sinspeel reeds op ' $n$ derde moontlikheid, of minstens 'n soepeler hantering van die saak.

Oor Petrus De Rivo is daar weinig biografies beskikbaar. Slegs een navorser, Christopher Schabel, professor in Middeleeuse Geskiedenis aan die Universiteit van Cyprus, spesialiseer in De Rivo as sodanig. Uit sy werk oor De Rivo (Schabel 19951996, 2000, 2005; kyk Baudry 1989 vir die groter konteks van De Rivo se lewe en debatvoering) blyk dat die Vlaam De Rivo gebore is as Petrus van den Becken rondom 1420 en gesterf het in 1500 . Hy het die grootste deel van sy lewe as dosent gewerk by die Fakulteit Lettere aan die Katolieke Universiteit Leuven, waar sy studies in 1437 'n aanvang geneem het. Hy het gepromoveer tot Magister Artium in 1442, van daar af na die teologiese kurrikulum beweeg en onderrig oor die Sententiae gegee, maar sou eers in 1477 promoveer tot Magister Theologiae.

In 1465 is De Rivo die volgende reguit en eenvoudige vraag deur ' $n$ student in ' $n$ quodlibetale debat by die fakulteit gevra: nadat Jesus aangekondig het dat Petrus hom drie maal sou verloën, was dit steeds binne Petrus se vermoë om Jesus nie te verloën nie? De Rivo het geantwoord: dit was binne Petrus se vermoë, maar dit is nie versoenbaar met die aanname dat wat Jesus aangekondig het noodwendig waar was toe Jesus dit aangekondig het nie. Ons moet eerder aanvaar dat sulke voorspellings nie noodwendig waar is of noodwendig vals is nie, maar eerder ' $n$ derde waarde naas 'waar' en 'vals' voorbehou, naamlik 'neutraal'. De Rivo verdedig met hierdie antwoord die ongewilde posisie van 'n voorganger, Petrus Auriolus in 'n soortgelyke debat 140 jaar vantevore. Die rede waarom De Rivo die blootstelling waag, is ter wille van die behoud van die nosie van vrye wil, ten alle koste. Om vrye wil ongeskonde te hou, ontken De Rivo enige determinering van toekomstige kontingentes voordat die kontingente manifesteer. Vir De Rivo, soos vir Auriolus voor hom, hou hierdie posisie 'n ontkenning van die toepassing van die beginsel van bivalensie in (op grond waarvan slegs twee waardes ten opsigte van die kontingente mag uitspeel, te wete 'waar' of 'vals'). 'n Stelling soos 'die Antichris kom' is nie waar of vals nie, maar neutraal (Schabel 2005:524). De Rivo implementeer vervolgens ander aspekte van Auriolus se posisie, onder meer dat God se kennis van die toekoms nie as 'voorkennis' in die streng sin van die woord verstaan moet word nie, nie as 'voorsienigheid' in die streng sin van die woord onderskryf hoef te word nie, en nie as ' $n$ predeterminering van die toekoms verstaan behoort te word nie: God gaan die toekoms nie vooraf of vooruit nie, maar is 'onbetrokke' en 'afstandelik' ten opsigte van die 'aktualiteite' van die toekoms (De Rivo, soos aangehaal deur Schabel 2005:524). Ten grondslag van hierdie verfynde posisie staan egter vierkantig die verwerping van die beginsel van bivalensie, wat De Rivo in ' $n$ uitgebreide korpus van geskrifte mettergaande tot sy dood toe sou verdedig.

Maar ten opsigte van die antwoord aan die student as sodanig, het De Rivo dadelik vuur getrek van 'n ou opponent, die Leuvense teoloog Hendrik van Zomeren. Van Zomeren se posisie was dat die Skrif wemel van toekomstige proposisies oor spesifieke gebeure, veral in die profesieë. Dit is volgens Van Zomeren net nie goed genoeg om te beweer dat hierdie profesieë op 'n later stadium waar sal word, maar ten tye van die uitspreek daarvan, neutraal in waarheidswaarde was/is nie. Tensy die profesieë waar was/is die oomblik toe dit uitgespreek is, is al die Bybelse profete leuenaars. De Rivo het opvolgend geargumenteer dat enige iemand wat die moontlikheid van 'n derde waarheidswaarde ontken, skuldig is aan die kettery van determinisme. Die universiteit het hom in hierdie reaksie amptelik in 1470 ondersteun. Van Zomeren het hom egter gewend tot Rome in die persoon van Kardinaal Bessarionus en die debat het ook buite Leuven hewige reaksie ontlok, veral by die teologiese fakulteite te Parys en Keulen.

'n Fransciskaanse logikus, Francesco delle Rovere, is opdrag gegee om te werk aan die logiese verhoudinge binne sodanige drieledige logika. Rovere argumenteer gevolglik dat die kontradiksie van ' $n$ waar proposisie selfevident ' $n$ vals proposisie moet wees, maar dat die kontradiksie van 'n neutrale proposisie nie vals is nie, maar self ook neutraal. Diegene wat dus die toekomsverwysende artikels van die belydenis ontken as waar maar as neutraal handhaaf, staan dus in onwaarheid voor die belydenis en behoort van dwaalleer aangekla te word.

De Rivo word opvolgend met die volgende stel grootliks bivalente proposisies vanuit die Van Zomeren kamp, en nou met pouslike sanksie daarvan, gekonfronteer (Kenny 2005:155): 
1. Vir 'n proposisie wat oor die toekoms handel om waar te wees, is dit nie genoegsaam dat dit stel wat in die toekoms sal gebeur nie: die proposisie moet stel dat dit onafwendbaar in die toekoms sal gebeur.

2. Rakende ' $n$ proposisie wat oor die toekoms handel, is daar net een van twee moontlikhede: daar is of geen teenswoordige en aktuele waarheid in die geloofsartikels oor die toekoms nie, of die geloofsartikels is reeds waar oor sake wat in die toekoms sal gebeur of nie sal gebeur nie.

3. Rakende ' $n$ proposisie wat oor die toekoms handel, is daar net een van twee belydenisse: of Goddelike mag het volledige beheer oor die toekoms, of daar is dinge in die toekoms wat nie tans of in die toekoms deur God beheer kan word nie.

De Rivo is gedwing om sy aanvanklike drieledige logika in die lig van bostaande proposisies se bewoording te verander en later volledig op te skort. Hy sou tot en met sy dood in 1500 werk aan ' $n$ alternatiewe bewoording wat sowel die onderliggende taalbegrip in terme van proposisionele struktuur as die logiese struktuur van sy argument sou kon ondervang. Hy kon nooit daarin slaag nie - die verhouding tussen taalbegrip en logika was eenvoudig te intiem: waar hy aan woorde verander het, het dit die logiese uitkoms van sy proposisies gekompromiteer.

Juis daarom is De Rivo, in al sy onbekendheid, die ideale figuur om hierdie reeks van twee artikels oor taalbegrip-logika in die Middeleeuse filosofie mee af te sluit: die debat by Leuven vanaf 1465 tot en met De Rivo se dood in 1500 illustreer hoe onmoontlik dit is, in die geskiedenis van die filosofie, om taalbegrip en logika te skei. Omdat formele logici in die 20ste eeu die eerste keer na Leuven weer ernstige oorweging aan ' $\mathrm{n}$ drieledige logika begin gee het en dit inderdaad gevolgryke resultate opgelewer het (vgl. Kenny 2005:155), is die episode by Leuven ook ' $n$ duidelik teregwysing aan sowel die hovaardige moderne as die spelerige postmoderne om selfs by onderbeklemtoonde figure in die Middeleeuse filosofie nie sonder meer, juis bivalent verby te gaan nie: inderdaad nie asof die post/moderne die laaste bivalensie oor die toekoms kan handhaaf nie.

\section{Erkennings \\ Mededingende belange}

Die outeur verklaar dat hy geen finansiële of persoonlike verbintenis het met enige party wat hom nadelig kon beïnvloed in die skryf van hierdie artikel.

\section{Literatuurverwysings}

Abelardus, P., 1919, Logica: Logica Ingredientibus \& Logica Nostrorum Petitioni, Beiträge zur Geschichte der Philosophie des Mittelalters, vol. 15, Münster, Beiträge zur
Aschendorff.

Adams, M.C., 1987, William Ockham, 2 vols., Notre Dame University Press, Notre Dame.

Ashworth, E.J. \& Spade, P.V., 1992, 'Logic in Late Medieval Oxford', in J.I. Catto \& T.A.R. Evans (eds.), History of the University of Oxford, Volume 2: Late Medieval Oxford, pp. 35-64, Clarendon Press, Oxford. http://dx.doi.org/10.1093/acprof: so/9780199510122.003.0002
Aquinas, T., 1964, Summa Theologiae, Blackfriars Edisie, 61 vols., Eyre \& Spottiswoode, Londen.

Aristoteles, 1995, 'Categoriae', in J. Barnes (ed.), The Complete Works of Aristotle, pp. 3-25, transl. J.L. Ackrill, Princeton University Press, Princeton.

Augustinus, 1992, Confessiones, ed., transl. \& comm. J.J.O'Donnell, vol. I-III, Clarendon, Oxford.

Baudry, L. (ed.), 1989, The quarrel over future contingents (Louvain 1465-1475), transl. R. Querlac, Dordrecht, Kluwer. (Synthese Historical Library, no. 36).

Beckmann, J.P., 1992, Ockham-Bibliographie 1900-1990, Felix Meiner, Hamburg.

Beukes, J., 2005, 'Terreur, roes en ordes: Die monnik as blywende simbool van erns in die filosofie', HTS Teologiese Studies/Theological Studies 61, 1101-1129.

Beukes, J., 2011a, 'God kan net doen wat God wel doen: Petrus Abelardus se Megariaanse argument in Theologia Scholarium, Opera Theologia III', in A.G. van Aarde Festschrift, HTS Teologiese Studies/Theological Studies 67(1), Art. \#124, 15 pages. http://dx.doi.org/10.4102/hts.v67i1.124

Beukes, J., 2011b, 'Die konstellasie taalbegrip-logika in die Middeleeuse filosofie (1): Augustinus Tot Aquinas', HTS Teologiese Studies/Theological Studies 67(3), Art. $\# 1072,15$ pages. http://dx.doi.org/10.4102/hts.v67i3.1072

Boethius, 1877, Commentarii in librum Aristoteles, Perihermeneias I-II, ed. C. Meiser, Teubner, Leipzig.

Boethius, 1978, De Topicis Differrentiis, ed. E. Stump, Cornell University Press, New York.

Bos, E. (ed.), 1998, John Duns Scotus (1265-1308) Renewal of Philosophy, (Medium Aevu Elementa), Amsterdam, Rodopi.

Bosley, R.N. \& Tweedale, M. (eds.), 2004, Basic issues in medieval philosophy: Selected readings presenting the interactive discourses among the major figures, Broadview Press, Ontario.

Broadie, A., 1995, The shadow of Scotus: Philosophy and faith in Pre-Reformation Scotland, T \& T Clark, Edinburg.

Colish, M.L., 1968, The mirror of language: A study in the medieval theory of knowledge, Yale University Press, New Haven.

Copleston, F.C., 1972, A History of Medieval Philosophy, Methuen, Londen.

Courtenay, W.J., 1987, Schools and scholars in fourteenth century England, Princeton University Press, Princeton.

Cross, R., 1999, Duns Scotus, Oxford University Press, Oxford.

De Rijk, L., 1962, Logica Modernorum, Van Gorcum, Assen.

Duns Skotus, J., 1950, Opera Omnia, Vatikaan Edisie, ed. C. Balic, Typis Polyglottis Vaticanis, Civitas Vatican.

Duns Skotus, J., 1968, Opera Omnia, Wadding Edisie, Georg Olms Verlagsbuchhandlung, Hildesheim.

Duns Skotus, J., 1997, Opera Philosophica, St Bonaventure, The Franciscan Institute Press, New York.

Gilbert, N.W., 1974, 'Ockham, Wyclif and the via moderna', in A. Zimmermann (ed.), Antiqui Und Moderni: Traditionsbewußtsein und Fortschrittsbewußtsein im späten Mittelalter, pp. 85-125, Miscellanea Mediaevalia, Berlin.

Gilson, E., 1955, History of Christian philosophy in the Middle Ages, Random House, New York.

Goddu, A., 1984, The Physics of William of Ockham, Brill, Leiden.

Haren, M., 1992, Medieval thought: The Western intellectual tradition from antiquity to the thirteenth century, University of Toronto Press, Toronto.

Heynick, V., 1950, 'Ockham-Literatur: 1919-1949', Franziskanische Studien 32, 164-183.

Hirvonen, V., 2004, Passions in William Ockham's Philosophical Psychology, Kluwer, Dordrecht.

Hispanus, P., 1971, Summulae Logicales, ed. L.M. de Rijk, Van Gorcum, Assen.

Hudson, A. \& Wilks, M., 1987, From Ockham to Wyclif, Blackwell, Oxford.

Hyman, A., 1973, Philosophy in the Middle Ages: The Christian, Islamic and Jewish traditions, Hackett, Indianapolis.

Ingham, M.B., 2004, The philosophical vision of Duns Scotus, Catholic University of America Press, Washington.

Kenny, A., 1985, Wyclif, Oxford University Press, Oxford

Kenny, A. (ed.), 1986, Wyclif in his times, Oxford University Press, Oxford.

Kenny, A., 2005, Medieval Philosophy, A New History of Western Philosophy, vol. II, Clarendon, Oxford.

Leff, G., 1958, Medieval thought: St Augustine to Ockham, Penguin, Harmondswort.

Leff, G., 1975, William of Ockham: The metamorphosis of scholastic discourse, Manchester University Press, Manchester.

Leppin, V., 2003, Wilhelm von Ockham: Gelehrter, Streiter, Bettelmönch, Wissenschaftliche Buchgesellschaft, Darmstadt.

Luscombe, D.E., 2004, Medieval Thought, Opus-Oxford University Press, Londen.

Marenbon, J., 2007, Medieval Philosophy: An Historical and Philosophical Introduction, Routledge, Londen.

Maurer, A.A., 1999, The Philosophy of William of Ockham in the Light of Its Principles, Pontifical Institute of Mediaeval Studies, Toronto.

Moody, E.A., 1935, The logic of William of Ockham, Sheed \& Ward, New York. 
Ockham, W., 1967-, Opera Philosophica et Theologica, eds. G. Gal et al., vol. 1 \& 3 of 17 , Franciscan Institute, Bonaventura, New York.

Oxford, University of, 2011, 'Famous Oxonians', viewed Mei 2011, from http://www. ox.ac.uk/about the university/oxford_people/famous_oxonians/index.htm

Price, B.B., 1992, Medieval thought: An introduction, Oxford, Blackwell.

Reilly, J.P., 1968, 'Ockham Bibliography: 1950-1967', Franciscan Studies 28, 197-214.

Robson, J.A., 1961, Wyclif and the Oxford Schools, Cambridge University Press, Cambridge.

Schabel, C., 1995-1996, 'Peter de Rivo and the quarrel over future contingents at Louvain: New evidence and new perspectives', Documenti e studi sulla tradizione filosofica medievale 6 (1995), 363 473, 7(1996), 369-435.

Schabel, C., 2000, Theology at Paris, 1316-1345: Peter Aureol and the problem of Divine foreknowledge and future contingents, Ashgate, Aldershot.

Schabel, C., 2005, 'Peter de Rivo', in J.J.E. Gracia \& T.B. Noone (eds.) A companion to philosophy in the Middle Ages, pp. 524-525, Wiley-Blackwell, Londen.

Spade, P.V., 1980, 'Synonymy and equivocation in Ockham's mental language', Journal of the History of Philosophy 18, 9-22.

Spade, P.V., 1995, Five texts on the medieval problem of universals, Hackett, Indianapolis.

Spade, P.V., 1999 (ed.), The Cambridge Companion to Ockham, Cambridge University Press, Cambridge.

Spade, P.V., 2006, 'Willam of Ockham', Stanford Encyclopedia of Philosophy, viewed January-May 2010, from http://plato.stanford.edu/entries/ockham
Sylwanowicz, M., 1996, Contingent, causality and the foundations of Duns Scotus' metaphysics, Brill, Leiden.

Tauchau, K.H., 1988, Vision and certitude in the Age of Ockham: Optics - Epistemology and the foundations of semantics, 1250-1345, Brill, Leiden. (Studien und Texte zur Geistesgeschichte des Mittelalters).

Tweedale, M., 1992, 'Ockham's supposed elimination of connotative terms and his ontological parsimony', Dialogue 31, 431-44. http://dx.doi.org/10.1017/ S0012217300012075

Vos, A., 2006, The philosophy of John Duns Scotus, Edinburgh University Press, Edinburg.

Vos (Jaczn), A., Veldhuis, H., Looman-Graaskamp, A.H., Dekker, E. \& Den Bok, N.W. (eds.), 2010, Contingency and Freedom: John Duns Scotus Lectura I 39, Springer www.springer.com, New York/Heidelberg.

Weinberg, J.R., 1964, A short history of Medieval philosophy, Princeton University Press, Princeton.

Williams, T. (ed.), 2003, The Cambridge companion to Duns Scotus, Cambridge University Press, Cambridge.

Wolter, A.B., 1990, The philosophical theology of John Duns Scotus, Cornell University Press, Ithaca/New York

Workman, H.B., 1926, John Wyclif: A Study of the English Medieval Church, 2 vols. Clarendon Press, Oxford.

Wyclif, J., 1985, Tractatus de universalibus, transl. A. Kenny, On Universals, P.V. Spade (intro. \& comm.), Clarendon Press, Oxford. 